\title{
A VÁROSSÁ NYILVÁNÍTÁS ELVI KÉRDÉSEI, POTENCIÁLIS VÁROSOK AZ ÉSZAKNYUGAT- DUNÁNTÚLON
}

\author{
(Principal issues of the declaration of new towns, potential towns in \\ Northwest Transdanubia)
}

CSAPÓ TAMÁS - KOCSIS ZSOLT

\section{Bevezetés}

A várossá válás mindig is izgatta a településföldrajzzal foglalkozókat, a regionális tudomány, a közigazgatás, a statisztika és még néhány tudományág képviselöit, az utóbbi néhány esztendőben mintha kissé háttérbe szorult volna. Ez annak ellenére van így, hogy a II. világháború óta soha nem volt olyan jelentós várossá nyilvánítási boom mint éppen az utóbbi öt évben, így a téma nagyon is aktuális.

A szakembereket mindig is foglalkoztatta a kérdés, mely településeket nyilvánítsunk várossá, milyen kritériumok alapján és hogyan múködjön ez a rendszer, milyen legyen a várossá válás folyamata. Ezek a kérdések, mint településföldrajzosokat, mindig érdekeltek, s a témához kapcsolódva az elmúlt években több tanulmányra ösztönöztek. (Csapó 1993, 1994, 1995). Emellett Intézetünkben 1995-ben két vizsgálat folyt, Csepreg és Répcelak várossá nyilvánításához szükséges elemzés elkészítése a települések önkormányzatainak a megbízásából.

Jelen tanulmány a fenti kérdésekre próbál meg választ adni, ugyanakkor az Intézetünkben folyó területfejlesztési vizsgálatok alapján megpróbálja kijelölni az északnyugat-dunántúli régiókban azokat a településeket, amelyeket a városi rangra alkalmasnak talál.

\section{A városodás föbb jellemzöi, hazánkban és az Északnyugat-Dunántúlon}

Az urbanizáció modern korunknak összetett és vitatott fogalma. Eredetileg a latin urbs (város) szóból ered és a városodási folyamatot jelzi, amelynek, értelmében létrejönnek és népességszámban bővülnek a városok. A XX. század közepétől egyre többen a városi életmód elterjedését, azaz a városiasodást is az urbanizáció jelentése mögé értették. Enyedi György szerint az urbanizáció kettős értelmủ térbeli folyamat, amely egyrészt a népesség állandó átrendezését jelenti a településhálózaton belül, másrészt a városi, technikai civilizáció, szokások, foglalkozások, fogyasztási és kulturális formák elterjedését is magában foglalja (Enyedi 1988).

Az urbanizációs folyamat alapvetỏen következmény jellegü, amely azt jelenti, hogy a termelőerók és a területi munkamegosztás szakadatlan bővülésénekfejlődésének a sokrétú vetülete. (Tóth 1988). Mivel a termelöerỏk fejlődése ciklikus 
folyamat, melyben rövid-, közép- és hosszú távú gazdasági, ún. konjunktúra ciklusok váltják egymást, így az urbanizáció is szakaszos, ciklikus kifejlődésủ folyamat (Lackó 1988). A modern értelmezésủ urbanizációs folyamat négy szakaszra különíthetö el: a városrobbanás, a viszonylagos dekoncentráció, a dezurbanizáció és az informatika urbanizációja (Enyedi 1988). Az urbanizáció szakaszai globálisan érvényesülnek, megjelenésüket a helyi tơrténelmi és földrajzi sajátosságok, a gazdasági fejlettség foka befolyásolja.

Közép-Európa, s benne hazánk urbanizációs fejlődése több tekintetben is eltér a nyugat-európai modelltől. A tókés fejlődés számára a történelmi feltételek a XVIII. ső́t még a XIX. század egy részében is kedvezötlenek voltak. Így az ipar nem bontakozhatott ki a szerves polgári városfejlỏdésből, hanem éppen fordítva: az iparosítás indította el a megkésett városfejlödést (Konrád - Szelényi 1971). Így hazánkban az urbanizáció első szakaszát - a városrobbanást - az ipari fejlődéssel való teljes összefonódás jellemezte. Hazánkban az első szakasz a múlt század 60-as éveitől kezdődött és lényegében az 1970-es évtized elejéig tartott.

A századfordulón 42 városi rangú település volt az ország mai területén. 1900 és 1920 között két, 1920 és 1945 között pedig további hat település kapta meg a városi rangot. Hazánk urbanizációs fejlődésének az elsỏ szakaszában 1945-ig tehát a városodásnak nem a városok számszerủ gyarapodása volt a legföbb jellemzője, hanem inkább a meglévö városok - kơzé mindenek elött Budapest - népességnek a gyors növekedése. A II. világháborút követően 50 város volt Magyarországon. A politikai fordulat után indult meg hazánkban a szocialista iparositással, az extenzív gazdasági fejlődéssel az urbanizáció első szakaszának a második része. Kezdetben, 1960-ig, nagyrészt a szocialista iparositás volt a meghatározó a várossá nyilvánításban. 1945 és 1960 között 13 település lett város, közülük 9 úgynevezett szocialista város, zömmel az ország energia tengelyében. Az 1960-as évtizedben újabb tíz települést nyilvánítottak várossá, így a városok száma 1970-ben 73 volt.

Enyedi György szerint hazánkban az 1970-es évtized elejétől kezdődőtt el az urbanizációs fejlődés második ún. relatív dekoncentráció szakasza. Ennek fó mozgatója a termelés intenzívebbé és a területi munkamegosztás erőteljesebbé válása az ország térségi fejlődésének a nivellálódásával egyidejüleg. A második szakaszban mérséklődik a népesség városokba vándorlása, ugyanakkor megkezdődik - s egyre jelentősebbé válik - a nem városi jogú, de/vagy városközeli vagy kedvezó helyzetben lévő településekbe a népességmozgás. Az urbanizációnak ezt a folyamatát nevezzük a rurális térségek városiasodásának mely gyakran együtt jár az agglomerálódással. Mindez szükségszerủen a falvak differenciálódását vonja maga után, a kedvező helyzetben lévő falusi jogállású települések lélekszáma megnő, funkciók bővülnek, az életmód a településen városiasodik, s mindez serkenti a várossá válási folyamatot. 1970-tôl húsz év alatt 93 települést nyilvánitottak várossá, így 1990-ben 166 városunk volt, a várossá válás tehát jelentősen felgyorsult.

A 80-as, 90-es évtized fordulójától kezdődően hazánk urbanizációs folyamataira egyre inkább az abszolút dekoncentráció, Egyedi szerint dezurbanizáció vált a jellemzővé. Ennek jeleként a városok népessége stagnál, sok esetben csökken, a népesség egyre inkább a rurális térségekben áramlik, jellemzővé válik a városiasodás. 
Mindez nagyjából egybeesik a politikai és gazdasági rendszerváltással is, melynek révén hazánk szakít a tervgazdasággal és a piacgazdaságra tér át. Ezzel egyidejüleg megváltoznak a katonai és politikai prioritások és új irányt kapnak a társadalmi folyamatok. Témánkra legnagyobb hatással az önkormányzati rendszer kialakulása volt a decentralizálási és a liberalizálási törekvések mellett. Fentiek hatására egyre több telepủlés kapta meg a városi címet. Az elmúlt hat évben 40 település - így 1996 végére a városok száma elérte a 206-ot Magyarországon.

A régió urbanizációs fejlődését döntỏen az országos folyamatok határozták meg, de hatottak rá a helyi regionális sajátosságok, legfóképp az, hogy a térség hogyan kapcsolódott, ill. illeszkedett be az ország terúleti munkamegosztásába. A régió, különösen Vas és Zala megye gazdasági fejlödése a II. világháború után szerény volt, döntỏen az akkor hátrányként jelentkezỏ nyugati fekvése és polgári hagyományai következtében. Mindez, párosulva az Északnyugat-Dunántúl aprófalvas településhálózatával visszafogta a városodást, nem segítette elő a várossá válást.

Az Északnyugat-Dunántúlon a századfordulón nyolc város volt, számuk a II. vilågháború végéig csupán eggyel bỏvült. 1945-1970 között hat település kapta meg a városi címet, Keszthely, Sárvár, Tapolca és Kapuvár régi sérelmei orvoslásaként, Ajka és Várpalota pedig új, szocialista város lett. 1970-ben a régióban 15 város volt, az ország városainak 20,5\%-a. 1970-es évtizedben Csomát, Balatonfüredet, Celldömölköt, Körmendet és Lentit nyilvánították várossá, így 1980-ra a városok száma 20-ra nőtt, ez 18,3\%-a az ország városainak. A legtöbb új város az 1980-as évtizedben jött létre a régióban, ekkor kapta meg a városi rangját Szentgotthárd, Zalaszentgrót, Sủmeg, Balatonalmádi, Vasvár, Zirc és Letenye. 1990-ben a 27 város az ország városainak 16,4\%-át jelentette. 1990-es évtized eddig eltelt éveiben újabb telepủléseket nyilvánítottak várossá, így jelenleg a régióban 30 város található, ez $14,6 \%$-a az ország városainak.

Az adatok ismeretében tehát úgy tünik, az Északnyugat-Dunántúlon kevésbé érvényesül a várossá nyilvánítási dömping, mint az ország más, zömmel alfỏldi térségeiben. Hiszen amíg országosan 1970 és 1996 között 134 telepúlés kapta meg a városi rangot, addig a régióban csak 15. Ebból fakadóan 20,5\%-ról (1970) 15,0\%-ra (1995) csökkent az ország városaiból a régióban található városok aránya.

$\mathrm{Az}$ Északnyugat-Dunántúlon egy városra átlagosan 28 falu jut, ez jóval magasabb az országos átlagnál $(14,2)$, amit a nagy településủrủség és a városok alacsony száma magyaráz. Különösen igaz ez Zala megyében, ahol minden városra 35,7 falu jut, ennél csak Baranya megye mutatói a kedvezőtlenebbek (1. táblázat). A régión belül legjobb az arány Veszprém megye esetében (23,9 falu/város), de ez is jóval magasabb az országos átlagnál. Ugyanakkor az Alfơldön csak Szabolcs-SzatmárBereg megyében jut tíznél valamivel több falu egy városra, a többi alföldi megyénél jóval tíz alatti a szám, kủlönösen Hajdú-Bihar (4,1), Jász-Nagykun-Szolnok (4,2) és Békés megyékben $(4,4)$, ahol nagy és óriás falvak jellemzőek és alacsony a településsűrüség.

Hasonló megállapításokat tehetünk, ha a városok arányát vizsgáljuk az egyes megyék összes telepủléseihez képest. Hazánkban ez az arány $6,6 \%$, az ÉszaknyugatDunántúlon csupán 3,4\%, azaz csaknem fele. A régió megyéit ez esetben is csupán Baranya megye "elözi” meg, régión belül Zala, Győr-Moson-Sopron, Vas és 
Veszprém megye a sorrend. Ezzel szemben az Alföld megyéiben - SzabolcsSzatmár-Bereg kivételével - minden tíz településböl legalább egy város, föként JászNagykun-Szolnok és Hajdú-Bihar megyében, ahol a települések közül majd minden ötödik városi rangú.

\section{TÁBLÁZAT}

A településhálózat jellemzöi a megyékben (1996)

Features of the settlement network in the counties (1996)

\begin{tabular}{|c|c|c|c|c|}
\hline Megye & Városok & Falvak & \multirow{2}{*}{$\begin{array}{l}\text { Egy városra } \\
\text { jutó } \\
\text { falu (db) }\end{array}$} & \multirow{2}{*}{$\begin{array}{c}\text { Városok aránya az összes } \\
\text { telepü- } \\
\text { léshez képest }(\%)\end{array}$} \\
\hline & \multicolumn{2}{|c|}{ száma $(\mathrm{db})$} & & \\
\hline Györ-Moson-Sopron & 6 & 167 & 27,8 & 3,5 \\
\hline Vas & 8 & 208 & 26,0 & 3,7 \\
\hline Veszprém & 9 & 215 & 23,9 & 4,0 \\
\hline Zala & 7 & 250 & 35,7 & 2,7 \\
\hline Komárom-Esztergom & 8 & 65 & 8,1 & 10,9 \\
\hline Fejér & 7 & 99 & 14,1 & 6,6 \\
\hline Baranya & 8 & 293 & 36,6 & 2,6 \\
\hline Somogy & 12 & 231 & 19,2 & 4,9 \\
\hline Tolna & 9 & 99 & 11,0 & 8,3 \\
\hline Bács-Kiskun & 15 & 103 & 6,9 & 12,7 \\
\hline Csongrád & 8 & 51 & 6,4 & 13,6 \\
\hline Békés & 14 & 61 & 4,4 & 18,7 \\
\hline Borsod-Abaúj-Zemplén & 16 & 339 & 21,2 & 4,5 \\
\hline Hajdú-Bihar & 16 & 66 & 4,1 & 19,5 \\
\hline Heves & 7 & 111 & 15,8 & 5,9 \\
\hline Jász-Nagykun-Szolnok & 15 & 63 & 4,2 & 19,2 \\
\hline Szabolcs-Szatmár-Bereg & 16 & 212 & 13,2 & 4,9 \\
\hline Pest & 18 & 166 & 9,2 & 9,8 \\
\hline Nógrád & 6 & 121 & 20,2 & 4,7 \\
\hline ENY-Dunántúl & 30 & 840 & 28,0 & 3,4 \\
\hline Ország összesen & 206 & 2920 & 14,2 & 6,6 \\
\hline
\end{tabular}

Forrás: Területi Statisztikai Évkönyv 1995. KSH Budapest.

Az Északnyugat-Dunántúlon tehát abszolủt számokban kifejezve is, de még inkább a településszámhoz viszonyítva, kevés a városban, egy városra átlag sok falu jut. Az országban Nógrád mellett Győr-Moson-Sopron megyében van a legkevesebb város (6 db), Zalában hét, míg Vasban és Veszprémben is csak nyolc, illetve kilenc város található.

\section{A városok központi funkciói, a várossá válás kritériumai}

A település hálózat elemei a magányos telepullések, a falvak, a városok és a agglomerációk/településegyüttesek (Mendöl 1963). A városok fogalma és tartalma mindig is vitát váltott ki a különbőző tudományágakban. A jogászok például azt mondják: az a település a város, amelyik megkapta a városi rangot. Az építészek szerint a város az a település, amelyben a beépítettség megfelelö horizontális zártsággal és bizonyos vertikális szintekkel jellemezhetö. A statisztikusok bizonyos 
népességszámhoz kötik a városi rangot. A földrajztudomány, ezen belül a településföldrajz, a funkciók oldaláról közelíti meg a kérdést.

A funkció szó jelentése: feladatkör, szerepkör, rendeltetés. Minden településnek vannak funkciói. Alapvetỏen a funkciók két csoportba sorolhatók: vannak alapfunkciók és központi funkciók. Alapfunkcióknak általában azokat a feladatköröket nevezzük, amelyekre az embereknek - a település lakóinak - a mindennapi megélhetés során van szükségük (lakás, alapvetö infrastruktúra, alap oktatási, egészségügyi és kulturális ellátás stb.). Ha egy telepưlés részben, vagy egészben csak alapfunkciókkal rendelkezik, úgy falunak tekinthetö.

A központi funkciók olyan magasabb szintü, ritkán - tehắt nem mindennap jelentkező feladatkörök, amelyek a szükségletek egy adott minőségi színvonalon történő kielégítésére szolgálnak. Ezek a szerepkörök nem lehetnek jelen a telepưléshálózat minden elemében, csak néhány centrumtelepülésen, melyek ezen központi funkciókkal nemcsak a saját lakóik szükségleteit elégítik ki, hanem környékük településeit is, azaz rájuk vonzást gyakorolnak.

Tehát azokat a településeket, amelyek központi funkciókkal rendelkeznek, s így vonzáskörzetük alakult ki, városoknak nevezzük, a központi szerepköröket városi szerepköröknek. Természetesen vannak olyan települések, amelyek noha rendelkeznek városi funkciókkal, jogilag azonban nem városi rangúak. Ugyanakkor van néhány olyan település is, mely városi jogállású, de városi-központi funkciója, $s$ így vonzás körzete nincs, vagy rendkívül fejletlen. A kérdés: meg lehet-e, meg kell-e határozni, melyek azok a kritériumok amelyek elérése esetén egy telepúlés várossá válhat?

Magyarországon a 23/1974. évi ÉVM-MTTH számú együttes közlemény, majd a 7010/1983. ÉVM számú irányelv foglalta össze a városi rang elnyerésének kritériumrendszerét, mindez lényegében 1990-ig fennállt.

A városi rangot pályázni lehetett, $\mathrm{s}$ az elbírálás során mérlegelték az adott községnek:

- a térségben betöltött ellátó, gazdasági és igazgatási szerepét, az ellátó funkcióit,

- a hasonló nagyságrendủ városokhoz viszonyított alapfokú ellátás színvonalát,

- az adott település külső megjelenését, rendezettségét,

- a történelmi, társadalmi hagyományait, értékeit,

- a telepủlésfejlesztési koncepciójának és területrendezési tervének a vonzáskörzetre is vonatkozó föbb céljait és irányait,

- a vonzáskörzetben és az adott településen múködö közigazgatási és gazdasági egységek, intézmények együttmüködését, a lakosság településfejlesztő tevékenységét.

A pályázathoz csatolni kellett a megyei közigazgatás, a végrehajtó bizottság állásfoglalását arra vonatkozóan, hogy a pályázó település várossá nyilvánitása összhangban van-e a megye terület- és településfejlesztési koncepciójával.

A pályázatok elbírálása mindezek alapján egyedi mérlegeléssel történt és kivételes esetben a hivatkozott rendelet lehetövé tette azt, hogy egy-egy kiemelkedö, sajátos szerepet betöltö telepưlés vonzáskörzeti funkció nélkül is várossá válhasson. A telepulés sajátos szerepét a rendelet nem határozta meg.

Ez a szabályozás a rendszerváltozást követően megváltozott. Lényeges változást az Önkormányzatokról szóló 1990. évi LXV. tv. 59. paragrafusa hozott, hiszen 
ennek értelmében az adott község kezdeményezheti várossá válását, nem szuikséges a megyei önkormányzat állásfoglalása. Azonban a benyújtott pályázat szakmai szempontok szerint történö egyedi elbírálása során változatlanul egyik lényeges kritérium a térségi szerepkör megléte, annak jellege.

$\mathrm{Az}$ elbírálás kritériumrendszerét a Belügyminisztérium Településfejlesztési és Kommunális Főosztálya állitotta össze, az alábbi tényezőkre figyelemmel:

- A telepúlés helye az ország telepúléshálózatában, kapcsolódása a közlekedésforgalmi rendszerekhez. A település múltja, történeti értékei, a korábbi városi, mezővárosi, igazgatási szerepköre, ennek ma is bizonyítható továbbélése, illetve hagyományai.

- A telepulés népességének alakulása, társadalmi szerkezete. A népmozgalom adatai (természetes és tényleges szaporodás, vándorlás stb.). A gazdasági aktivitás, a foglalkoztatottság, az ingázás, a képzettségi jellemzők.

- A telepuilés gazdasági fejlődése, a község és a térség lakosságát is foglalkoztató gazdálkodó szervezetek, társulások, egyéb intézmények jellemzői.

- A telepúlést, illetve térséget ellátó középfokú intézmények bemutatása, melyek közül kiemelten fontos az oktatás, a kulturális, illetve az egészségügyi és szociális ellátás egységei (középiskola, kollégium, népföiskola, mủvelödési-, falu-, tájház, illetve kórház vagy szakorvosi rendelőintézet, mentỏállomás, szociális intézmények stb.). Továbbá lényeges a helyi, térségi múkỏdésú igazgatási és rendészeti szervek (pl. bíróság, földhivatal, rendőrség, tủzoltóság stb.), illetve a müszaki infrastrukturális ủzemegységek (pl, áramszolgáltató, kommunális) jellemzése.

- A telepulés kereskedelmi és bevásárlóközponti szerepe, szolgáltató egységei (áruházak, bolti kiskereskedelmi forgalom, ezen belül iparcikk forgalom stb.).

- A település idegenforgalmi jellege, intézményei, férőhelyei (szálloda, panzió, kereskedelmi szálláshely stb.), illetve a szabadidỏ eltöltésének lehetőségei, intézményei (strand, uszoda, szabadidöközpont, tornacsarnok stb.) és környezeti kultúrája.

- A telepúlés múszaki infrastruktúra-ellátottsága: a villany-, gázellátás módja, a közmüves vízellátás, a szennyvízelvezető csatornahálózatának kiépitettsége, a szennyvizelvezetés mértéke, a rendszeres szemétgyüjtés és lerakás megoldottsága, út- és hírközlési hálózatának kiépitettsége. A tömegközlekedés belső rendszere, módja.

- A település szellemi vonzása és kulturális színvonalának jellemzöi. Az öntevékeny szervezetek (egyesületek, társaságok, alkotó és egyéb közősségek stb.) létének és aktivitásának bemutatása.

- Az önkormányzati gazdálkodás jellemzöi, a tárgyév költségvetési mérlege. A fejlesztések ismertetése.

- A település városias arculatának jellemzői: rendezettsége, központjának városiassága, épületeinek, épulletegyütteseinek megjelenése, müemlékei, környezeti állapota. A község településfejlesztési elgondolásai, a településrendezési tervek, az épített környezet védelmére tervezett intézkedések. 
- A község térségi szerepe és súlya (gazdasági, foglalkoztatási, az intézmények szervezö és vonzó hatása, társulások mértéke stb.).

A Belügyminisztérium a beérkezett pályázatokat elbírálja, melynek során összeveti az egyes települések mutatóit a magyar kisvárosok (20 ezer alattiak) átlagmutatóival. Négy csoportba osztva (népesség, lakás, infrastruktúra, tercier funkciók) 23 átlagmutatót jelöltek $\mathrm{ki}$, amelyek statisztikailag jellemzik a településeket. Le nem irt követelmény, de gyakorlat, hogy egy település akkor pályázhat eséllyel városi rangra, ha ezen kisvárosi átlagokat többségében eléri, vagy meghaladja. Ezután a Minisztérium szakemberei a helyszínen is szemrevételezik a pályázó falut, majd véleményt alakítanak ki, mely ha pozitív, felterjesztik az államföhöz a várossá nyilvánításra.

Az MTA RKK Nyugat-magyarországi Tudományos Intézete Vas Megyei Kutatócsoportja 1994-ben a fenti kritériumrendszer alapján megvizsgálta, hogy az Északnyugat-Dunántúlon mely település alkalmas a várossá válásra a közeljövöben. A kutatás során az ún. TINA-2 (településszintủ innovációs adatbázis) több száz adatát elemeztük, 15 különbözö szakcsoportban. Figyelembe vettük a BM ajánlásait, az elsö rostán bennmaradt településeket viszonyítottuk a magyar kisvárosok átlagaihoz (Csapó-Kocsis 1994). Várakozásainknak megfelelöen csak néhány település maradt fönn a kétszeres, de alapvetöen csak statisztikai rostán. Győr-Moson-Sopron megyéböl Fertöd és részben Tét, valamint Jánossomorja, Vasban Bük, Csepreg és részben Répcelak, Veszprémben Devecser és részben Herend, míg Zala megyében Zalalövő ás Zalakomár. Véleményünk szerint a várossá válás jelenlegi feltételrendszerén és folyamatán változtatni kell. Tudomásunk szerint megindult egy ilyen irányú vizsgálat, ehhez kivánunk jelen tanulmány eredményeivel hozzájárulni.

A térség városhálózata tisztán a népességszám szerint kiegyensúlyozottnak mondható, a nagy-, a közép- és a kisvárosok száma és aránya tulajdonképpen megfelelö lenne. Területi eloszlásuk viszont már számos problémát felvet. Az Északnyugat-Dunántúl hagyományosan policentrikus térség. Bár Gyór vezetó szerepéhez összességében nem fér kétség, regionális funkcióit tekintve nem teljes értékủ központ. Gazdasági súlya mellett kisebb jelentőségủ igazgatási, felsöoktatásikutatási központ léte. Ezért a térség más megyeszékhelyei, illetve más városai is rendelkeznek a megyehatárokon messze túlnyúló szerepkörökkel. Ez a munkamegosztás talán elönyösnek is felfogható lenne, de a központok ilyen "demokratizmusa" sem enyhítheti azt a körülményt, hogy a legfontosabb centrumok (a megyeszékhelyeken túl még Sopron, Nagykanizsa, illetve Keszthely, Mosonmagyaróvár, Pápa) szinte mind kifejezetten saját megyéjük és a térség peremén helyezkednek el.

Sajnos, az említett telepủléseken kívül alig találni középvárost, kisvárost, amely a megyeszékhely viszonylagos távolságát fejlettebb intézményi-, kereskedelmi-, stb. funkciói alapján enyhíteni tudná, föleg nem a régió viszonylatában, megyehatáron áthatoló érvénnyel.

A térségre tehát azt mondhatjuk, hogy bizonyos belső területei megyeszékhelyhiányosnak bizonyulnak, több központ között a senki fơldjén, gyengén ellátva fekszenek. 
Győr-Moson-Sopron megyében a Győr-Csorna-Kapuvár-Fertỏd-Sopron vonaltól délre találni ilyen városhiányos térséget, Zalában pedig a megye kellös közepén. Veszprém megyében a Bakony természetes akadályként a településhálózatot és a közlekedési kapcsolatokat is erösen befolyásolja, de a többi megyében komolyabb domborzati oka nincs, alig lehet a perifériák kialakulásának.

Nem sokkal jobb a helyzet Vas megyében sem, mert itt Szombathely abszolút túlsúlyához képest a többi kisváros gyenge, de nagyobb városhiányos területek igazából csak ott alakulnak ki, ahol a szomszédos megyében sem találni erösebb centrumot.

Egy hosszan elnyúló zóna található a régió északi felében, ahol Sopron-FertődKapuvár-Csorna-Györ, illetve Köszeg-Csepreg-Sárvár-Celldömölk-Pápa-Zirc városok által határolva a megyeszéli perifériák egymás mellé kerülésével egy városhiányos övezet jött létre. Kisebb központjai sem tudják megoldani a tér funkciókkal való teljes lefedését, közlekedési kapcsolatai alapján is egy észak-dél irányú átmeneti, sok tekintetben tranzit jellegủ térségnek tekinthető.

Kiterjedésében kisebb, de szintén több megyére terjed a Győr-Csorna-KapuvárSárvár-Celldömőlk-Zalaszentgrót-Sümeg-Ajka-Pápa-Györ határokkal kijelölhető terület. Közlekedési kapcsolatai a Györ-Pápa, illetve Györ-Sárvár irányokban fejlettebbek, ezért inkább déli része a problematikus, ahol gyenge kisvárosi centrumok találhatók.

A harmadik nagy, összefüggő térség a Körmend-Zalaegerszeg-ZalaszentgrótHévíz-Keszthely-Nagykanizsa-Letenye-Lenti-Szentgotthárd-Körmend körön belül fekszik. A potenciális központok közül Zalalövő és Öriszentpéter a városhiányos térség nyugati részét lefedné, Zalakomár a Keszthely-Nagykanizsa közötti vákuumban nyerhetne térségi funkciókat, de Bak község semmiképpen sem tünik alkalmasnak arra, hogy Zala megye belsö területei számára városias szerepköröket hordozzon. A két megyei jogú város, Zalaegerszeg és Nagykanizsa megerösödése esetén is ellátatlan maradna az őket képzeletben összekötő vonaltól nyugatra-délre elterülő vidék, mert Lenti és Letenye csak részben tudnak megfelelni városi szerepkörüknek.

A régió városhálózatára tehát elmondható, hogy a megyeszékhelyek közötti funkciómegosztás nem azért alakult ki, mert több egyformán jól fejlett, életerős centruma van a térségnek, hanem azért, mert egymagában egyik város sem tudja ellátni a négy megyényi teruletet.

Győr-Moson-Sopron megyében a két tradionális központ, Győr és Sopron közöttti térségben található kisvárosok nem mindenben tudják kiegészíteni a történelmi megyeszékhelyeket, sőt sok tekintetben saját vonzásterületük ellátására sem futja erejükböl.

Vasban a megyeszékhely túlzott súlyát alig tudják enyhíteni a kisvárosok, Sárváron kivül egyik sem tud teljes mértékben megfelelni feladatának, ezért a megye délkeleti részén kiterjedt városhiányos terület alakult ki.

Veszprém megyében a domborzati viszonyok következtében a megye északnyugati egyharmada szinte el van vágva székhelyétől, Pápa és részben Ajka azonban sokkal erőteljesebb pótlói, kiegészítői a Veszprémnek ebben a térségben, mint a két korábbi megye kisvárosai. 
Zala megyét a két rivális központ közötti ür, illetve néhány kisváros kivételével a teljes periféria városhiányos, sỏt a megye centrális helyzetủ belső területeinek volta sújtja.

A régió városhiányos területeinek kialakulásához egyaránt hozzájárul a nagyobb központok viszonylagos gyengesége, a megyehatár menti perifériák "összeadódása", a domborzati viszonyok, valamint a hagyományos aprófalvas településszerkezet. Ez utóbbi következtében a potenciális városok többsége tulajdonképpen a nagyközség méretkategória alsó határa körül helyezkedik el, ezért várossá avatásuk után is csak viszonylag gyengébb tẻrségi hatást lesznek képesek kifejteni.

\section{Javaslatok a várossá válás új feltételeihez és folyamatához}

A jelenlegi szabályozás alapjaként megfogalmazott tétellel - miszerint egy várossal szemben bizonyos kritériumokat kell érvényesíteni - egyetértünk, mivel ellenkezö esetben minden település várossá válhatna. A kérdés az, hogy milyen feltételek legyenek, azok mennyire legyenek adatszerủek, mérhetók akár abszolút számban, akár fajlagosan pl. \%-ban, illetve a feltételeket egységesen kell-e megállapítani országosan, vagy lehetnek regionális különbségek. A korlátozott terjedelem nem teszi lehetővé a részletes, mindenre kiterjedó állásfoglalást, ezért csak az általunk legfontosabbnak ítélt kritériumokkal foglalkozunk.

\section{Feltételek}

Népességszám: Egyre többet hallani arrol, hogy meg kell állapítani egy limitet, három-, négy- vagy ötezer fơt, és csak az afölötti települések lehessenek városok. Ez a kritérium semmiképpen nem támogatható, legyen egy kívánatos lélekszám, de ne rendelkezzen vétóval. Hiszen ha pl. 5 ezerben húznánk meg a határt, az aprófalvas térségekben, az Északnyugat-Dunántúlon is csak három település (Jánossomorja, Berhida és Devecser) lehetne város. Ha a határ 4000 fó lenne, a régióban elvben 5 település, ha 3000 úgy 18, s ha 2000 fónél lenne meghúzva lélektani határ, akkor is csak ötven telepủlés pályázhatna a városi rangra. Ugyanakkor például egy kétezres határ esetében csaknem az összes alföldi falu elvileg város lehetne.

Javasoljuk, a népességszám alsó határa 2000 fỏ legyen, hasonlóan több nyugateurópai országhoz, de ez csak egy feltétel legyen, ne pedig kizáró ok, és egyes nagyon indokolt esetekben (városhiányos térség, területfejlesztési szempontok, speciális funkciók) még ettöl is el lehessen térni.

Funkciók: Úgy véljük, egy várossal szemben alapkövetelmény, hogy rendelkezzen központi szerepkörökkel, mind a primer, a szekunder, illetve a tercier funkciók vonatkozásában. Településföldrajzos lévén úgy gondoljuk, egy település éppen a központi funkciók tesznek várossá. Következtében vonzása van a településnek, a környező falvak centrumnak tekintik, ahová lakóik vásárolni, dolgozni, tanulni, szórakozni, gyógyulni és ügyet intézni mennek. Feltételként ezt is rugalmasan kell kezelni, hiszen ez esetben sokszor az alföldi nagy lélekszámú telepưlések kerülhetnek hátrányba, hiszen központi funkciók ellenére vonzásuk nincs vagy kicsi, mivel sok esetben a környező települések is már városok. 
Intézmények: $\mathrm{Az}$ intézmények léte összefügg a központi funkciókkal és a lélekszámmal. $\mathrm{Ha}$ a jelenlegi $\mathrm{BM}$ ajánlásokat szigonúan vennénk, akkor az aprófalvas Északnyugat-Dunántúlon lehetetlenné tennénk a mégoly városias mutatókkal rendelkezö falvak várossá válását is, mivel a régióban szinte alig lehet találni pl. kórházat, középiskolát a nem városi telepưléseken. Így véleményünk szerint minimumokat kellene felállítani, például teljes képzésú általános iskola, óvoda, művelődési ház, múzeum vagy gyüjtemény, szakorvosi rendelőintézet, vagy rendelések, gyógyszertár, valamilyen szociális létesítmény, pénzintézet, több kereskedelmi létesítmény, kereskedelmi szálláshelyek, sportlétesitmények, amelyek egyébként az aprófalvas térségekben már többnyire központi funkcióknak is számítanak, s így vonzást is gyakorolnak a térségre. A lényeg, hogy a funkció és intézményei következtében legyen a településnek térszervezö szerepköre.

Infrastruktúra - kommunális ellátottság: Kétségtelen, hogy elvárható egy leendő várostól az, hogy fejlett infrastruktúrája, s megfelelö minőségú legyen a kommunális ellátottsága. Azonban nem tartjuk szerencsésnek ha fajlagos mutatókkal normatívákat alkalmazunk és követelünk meg. A fajlagos mutatók terén találni jó néhány anomáliát, melyek többsége az adott telepullés egyedi helyzetével függ össze. A vezetékes gázzal ellátott lakások aránya például ott magas, ahol egyáltalán létezik vezeték. Telefonellátottság ott magas, amely telepullés be van kötve a távhívású hálózatba, ott nagy a csatornázott lakások aránya, ahol egyáltalán csatornázva van a telepulés. Másrészt éppen az infrastruktúra és a kommunális rendszerek tekintetében mutatható ki legkevésbé markáns különbségek kisvárosok és a falvak között, sok esetben a falvak mutatói jobbak.

Városias arculat: Fontos szempont lehet a települések morfológiája, s rendezettsége, megjelenése, környezeti állapota. Azonban ezt a feltételt is térségenként más és másképp kell megitélni. Ez tudniillik az Alföld jellegzetesen agrár-óriásfalvait hozná nehéz helyzetbe, hiszen ott nem jellemzó a település vertikális tagozódása, többnyire falusias a településkép, s mindez csökkenti a település városiasságát. Ugyanakkor szigorúbban kell figyelembe venni a község telepưlésfejlesztési elgondolásait, a településrendezési terveket, az épített környezet védelmére tett/tervezett intézkedéseket.

Szellemi kisugårzás: A legnehezebb ezt a feltételt megfogni s értelmezni, pedig véleményünk szerint ez az egyik legfontosabb. A szellemi kisugárzást alapvetóen a telepửés funkciói, intézményei, hagyományai, történelme, de leginkább talán az ott élt és az ott éló lakosok, az emberek cselekedetei, tudata, viselkedése és összetartása adja. Itt jelennek meg erősen és pozitívan a település egykori városi létéböl fakadó tradíciók, hagyományok és emlékek, melyek kétségtelenül segítik a várossá válást.

Településfejlesztés - térségi szempontok: A várossá nyilvánítás szerintünk soha nem lehet öncélú, azaz csak az adott telepưlés érdeke. A várossá nyilvánítás meggyöződésünk szerint a területfejlesztés egyik fontos eszköze. Különösen igaz ez Észak-Magyarországon és a Dunántúlon, ahol sürübb a településhálózat és apróbbak a falvak mint az Alföldön. Ebböl fakadóan a várossá nyilvánításkor a térségi szempontok figyelembevétele rendkívül fontos. Itt elsősorban a városhiányos térségekre gondolunk, ahol van centrumtelepülés, vonzása öt-tíz, néha jóval nagyobb településkörre terjed $\mathrm{ki}$, ahol a centrum várossá válása nem elsösorban a település érdeke, hanem inkább a térségé. Véleményünk szerint ilyen esetekben, a 
megyei, vagy regionális területfejlesztési stratégiákkal összhangban olyan kisebb település is kaphatna városi rangot, amely a feltételrendszer egyes elemeit nem tudja egyébként teljesíteni.

Az Északnyugat-Dunántúl területfejlesztési stratégiảjában éppen a fenti pontok, különösen a térségi szempontok figyelembevételével, továbbfejlesztve korábbi vizsgálatunkat több települést javaslunk a városi rang elnyerésére. Középtávon (2000-ig) Györ-Moson-Sopron megyében Jánossomorja és Tét, Vas megyében Répcelak, Bük, Veszprém megyében Devecser és Herend, Zala megyében Zalalövö és Zalakomár nagyközségeket (I.ábra). Hosszú távon pedig (2010-ig) indokolt Beled és Pannonhalma (Györ-Moson-Sopron), Jánosháza és Öriszentpéter (Vas), Nagyvázsony és Balatonfüzfö (Veszprém), valamint Bak (Zala) várossá nyilvánitása. Ezzel az Északnyugat-Dunántúl négy megyéjében összesen 45 város lenne, $\mathrm{s}$ az egészséges városhálózat lényegében kialakulna.

\section{1. ÁBRA}

Az Északnyugat-Dunántúl városhálózata

Urban network of Nortwest Transdanubia

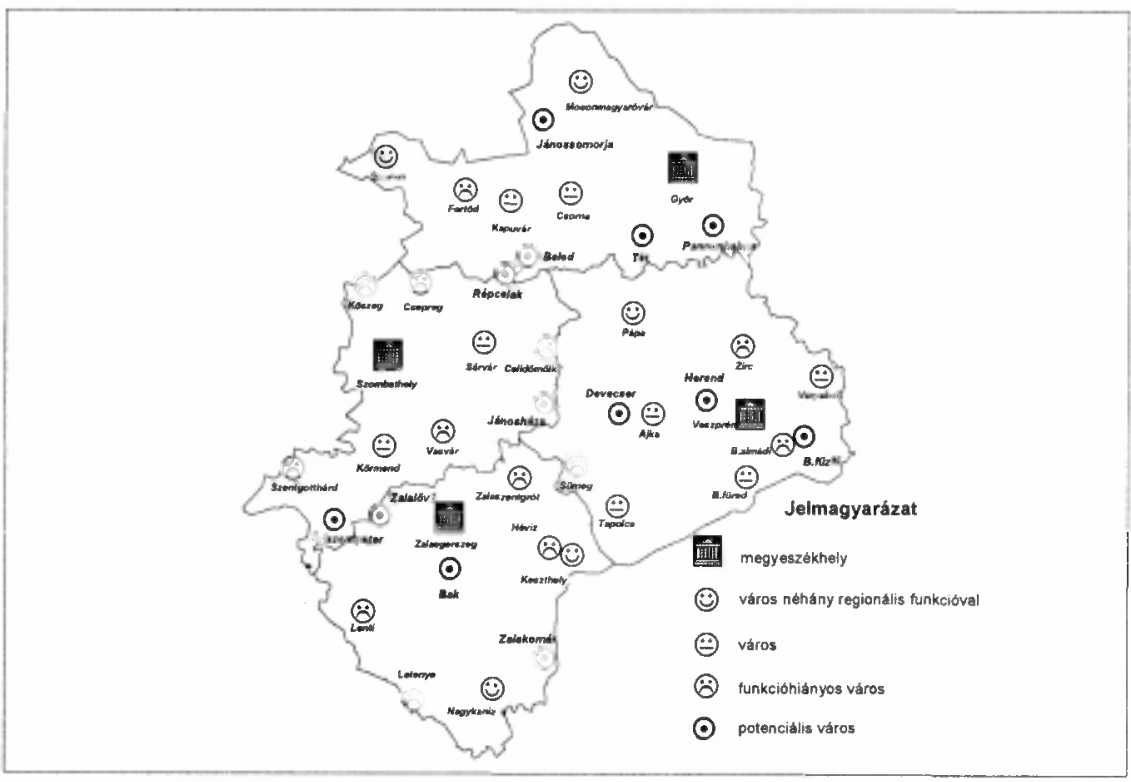




\section{A várossá válás közigazgatási aspektusai}

Alapvetően egyetértünk az igazgatás mai gyakorlatával, miszerint a kezdeményezésnek alulról, a településtöl kell indulnia. Erről dönteni kell az önkormányzatnak s el kell készíteni/készíttetni egy minden szempontból korrekt vizsgálatot, anyagot a településröl, amely feldolgozza és bemutatja a települést, nagy hangsúlyt helyezve a feltételrendszer elemeire. Ezt az anyagot mind az önkormányzatnak, mind a falu lakosságának ismernie s elfogadnia kell. Nagyon lényeges kérdés, hogy a község lakói azonosuljanak a várossá válási törekvésekkel, az ne csak az önkormányzat véleménye legyen. Hadd álljon itt példaként Bük nagyközség esete, ahol a tanulmány elkészült, az önkormányzat elindította a kezdeményezést, de a falu lakói leszavazták azt, ök - lévén, hogy Bük jelentös termál-falusi turizmust bonyolít le - nem akartak várossá válni. A nagyközség egyébként csaknem minden feltételnek eleget tett volna.

A pályázat a Belügyminisztériumba kerül, ott szakemberek elbírálják, személyesen ellátogatnak a településre, majd pozitiv elbírálás esetén felterjesztik az államföhöz, aki aláírja az okiratot, mellyel a település városi rangú lesz.

A folyamat alapvetően helyes, de hasonlóan az 1990-es önkormányzati törvényhez, véleményưnk szerint túlzottan liberális. Hiányzik a folyamatból a középszint, a térség állásfoglalása és véleménye. Egy települést, mint azt kifejtettük, vonzása, funkciói, azaz térségi szerepkörei teszik várossá, ezért véleményem szerint a települési és országos szint között meg kell jelenni a térségi érdeknek, véleménynek. A középszint lehet a megyei önkormányzat, a területfejlesztési törvény elfogadása után megalakuló területfejlesztési tanácsok, vagy településszövetségek, kistérségi szervezödések. Egy a lényeg, a várossá válások ne öncélúak legyenek, ne egy település érdeke legyen, hanem egy térségé.

A várossá válási folyamat tervszerủ kell hogy legyen, el kell készíteni a megyék és kistérségek területfejlesztési stratégiáit, s azokban szerepelnie kell a prioritások között, hogy mely települések várossá válása indokolt az adott térségek fejlödése miatt a közeli, vagy a távolabbi jövőben.

\section{A városi szerepkörböl - rangból - fakadó elönyök és hátrányok}

Ha a rendszerváltás elötti évtizedeket nézzük, azt kell mondani, hogy a városi rang elnyerése egyértelmüen előnyökkel járt. Nemcsak rangot, presztízst jelentett, hanem az akkori területi politikának, redisztribúciós rendszernek megfelelően kiemelt fejlesztést, több pénzt, hatalmat. Napjainkban a változások ellenére megállapitható, hogy bár a területi politika egyértelmüen kístelepülés - falu - párti, a városi vagy községi jogállás nem lényegtelen a település fejlỏdése, esetlegesen a társadalmigazdasági nehézségeiből történő kilábalás vonatkozásában. Egy adott település fejlödése nemcsak a minisztériumok, a közigazgatás döntésein múlik, hanem a helyi társadalmi-gazdasági-politikai szereplők hozzáállásán, település-területfejlesztési törekvésein is. Egy város, éppen társadalmának, gazdaságának összetettsége és fejlettsége, a társadalmi-gazdasági élet szereplöinek hozzáállása, a társadalom rétegeinek, csoportjainak egyre markánsabban megjelenö életkörülmények és 
jövedelmi viszony szerinti differenciálódása és ebböl fakadó elvárásai miatt érdekeit jobban képes képviselni, mint a kisebb települések.

A probléma nem is ebböl, hanem a hatáskörök és a jelenlegi finanszirozási rendszer ellentmondásából fakad. Hiszen általános értelemben a községek úgymond „kötelezhetök” közvetett módon a finanszírozás módszereivel az alapellátási funkciók gyakorlására, csakúgy mint a városok a térségi középfokú ellátására. Ugyanakkor a városok - föleg a kisvárosok - a mai finanszírozási szisztémában a leghátrányosabb helyzetben levő települések a településhálózatban. Így nem véletlen, hogy nem képesek középfokú városi funkcióikat gyakorolni, $\mathrm{s}$ szerepköreiket kénytelen átadni más - többnyire a megyei önkormányzatnak. Nem egyedi eset ez Vas megyében, lásd a kőszegi mezögazdasági szakkőzépiskola, illetve a körmendi szakközépiskola és szakmunkásképzö esetét. Szomorú ellentét ez, hiszen egyrészt a városi rang elnyerésénél az országos szervek szigorú feltételrendszert érvényesítenek, ugyanakkor a középfokú - különösen - oktatási funkciók finanszírozási feltételei nem megfelelöek.

Azon települések esetében, amelyek történetük során voltak már városok, de a rangot elveszítették, a várossá válás igen fontos szociológiai, pszichológiai tényezỏ lehet, így erösítheti az azonosságtudatot, nagyobb összefogásra, cselekvésre ösztönözhet, spontán fellendülést okozhat (lásd Csepreg példáját Vas megyében).

\section{Irodalom}

Csapó-Kocsis (1994) Kistérségi központi funkciók ellátását végző, vagy arra alkalmas települések, potenciális városok Vas megyében. Térségi folyamatok a Nyugat-Dunántúlon 1. sz. MTA RKK Szombathely, 57 o.

Csapó (1993) Az alapellátottság vizsgálata Észak- és Nyugat-Dunántúl falusi településeiben. Gyôri tanulmányok 12. évf. Györ, 47-68. o.

Csapó (1994) Az urbanizációs folyamat és sajátosságai a Nyugat-Dunántúlon. UNIPRINT Kft Szombathely, 180 o.

Csapó-Rechnitzer (1995) Vas megye területfejlesztési prekoncepciója. Nyugat-magyarországi Tudományos Intézet Közleményei 12. sz. Szombathely, 62 o.

Enyedi (1988) A városnövekedés szakaszai. Akadémiai Kiadó, Budapest, 116. o.

Konrád - Szelényi (1971) A késleltetett városfejlődés társadalmi konfliktusai. Valóság 12, sz.

Lackó (1988) Területi fejlódés, politika, tervezés. Akadémiai Kiadó, Budapest, 196 o.

Mendöl (1963) Altalános településföldrajz. Akadémiai Kiadó, Budapest.

Rechnitzer (1993) Szétszakadás vagy felzárkózás. A térszerkezetet alakitó innovációk. MTA RKK, Györ 2080.

Tóth (1988) Urbanizáció az Alfôldón. Területi és települési kutatások. 3. Akadémiai Kiadó, Budapest 1850 . 


\title{
PRINCIPAL ISSUES OF THE DECLARATION OF NEW TOWNS, POTENTIAL TOWNS IN NORTHWEST TRANSDANUBIA
}

\author{
TAMÁS CSAPÓ - ZSOLT KOCSIS
}

In Hungary the network of the towns has not yet developed fully, making the declaration of another 50-80 settlements as towns justifiable in the coming 10-15 years. Most of the settlements to be declared as towns can be found in regions dominated by small and tiny villages, i.e. in North Hungary and Northwest Transdanubia.

In this latter region, 15 settlements should be ranked as towns in two steps. In the first phase (until the year 2000) Jánossomorja, Tét, Bük, Répcelak, Devecser, Herend, Zalalövö and Komár, in the second phase (until 2005-2010) the settlements of Beled, Pannonhalma, Jánosháza, Öriszentpéter, Nagyvázsony, Balatonfüzfő and Bak should be given town status.

This would not modify the spatial structure of the region to a large extent, but the new small towns would significantly decrease the number and surface area of the regions that are in want of towns at the moment, although they will probably be too weak for a long time to eliminate the inner peripheries.

The town rank of the aforementioned small centres will only bring real results if they develop and expand in their functions. With respect to retail trade and administration, most of them can now be regarded as towns, central places, but their roles in health care, economy, especially employment has to be strengthened. The single most important issue, however, is settling down secondary education in these settlements.

The would-be towns thus need to develop in the first place their institutional infrastructure and their own economy, and only in the second place the communal infrastructure, as this is also the priority order of the functions which make them towns of their environment.

The acquisition of the town status should continue to be conditional, but the criteria should be flexible, suited to the differences in the regional and settlement network. The desirable number of population is around 2000 , but this criterion, as each of the others, should not have an absolute right of veto. A criterion of special importance should be the central function, spatial organising power of any settlement.

The criteria of obtaining the town status should be separated. A system of criteria based primarily on statistical and quantitative-qualitative indices should be set for those settlements in the case of which it is only to the advantage of the given settlement to become a town, as in many cases they have no real catchment area (large villages and old agricultural towns in the Great Hungarian Plain, sleeping villages of the Budapest agglomeration); another set of conditions should be defined for those settlements where their region and surrounding settlements have a vested interest in the given settlements obtaining town status, maybe an interest bigger than they themselves have.

In the process of the declaration as town the role of the medium level has to be strengthened. Becoming a town should be a planned process which also appears in the small regional, county and regional development concepts. The initiatives should of course continue to come from the bottom, the settlement level. 